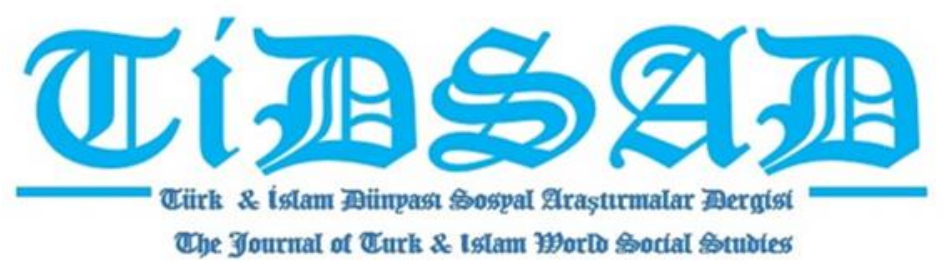

Yıl: 7, Sayı: 26, Eylül 2020, s. 65-74

\title{
Mehmet ÇOTU
}

MEB, Arap Dili ve Edebiyat1, mehmetcotu@gmail.com

\section{MODERN ARAP EDEBIYYATI VE MODERN TÜRK EDEBIYYATINDA ELE ALINAN BENZER KONULAR VE YAZARLARI}

Özet

1798'de Napolyon'un Mısır'ı işgal etmesi ile Arap dünyası, 1839'da Tanzimat dönemiyle de Türk dünyası, Batıyla kaynaşma sürecine girmiştir. Her iki edebiyat dünyasında da benzer tarz eser ve yazarlar ortaya çıkmıştır. Buna bağlı olarak Yusuf Kâmil Paşa ve Rıfa’t et-Tahtavî, “Telemak” adlı eseri çevirmişlerdir. İlk köy romanını, Nabızâde Nazım ve Hüseyin Heykel vermiştirler. Fuat Köprülü ve Sadık er-Râfî ise edebiyat tarihçileridirler. Cemal Kuntay ve Taha Hüseyin ise üç kuşak örneklerini ortaya koymuşlardır. Ahmet Hamdi Tanpınar ve Tevfik el-Hakim de doğu-batı çatışmasını ele almışlardır. N. Fazıl Kısakürek ve Necip el-Keylânî de Hz. Muhammed'in (s.a.v.) hayatını roman tarzında anlatmaya çalışmışlardır. M. Akif, Süleyman el-Bârunî ile Sadık er- Râfî vatan temasını ele almışlardır. H. Edip Adıvar, Nazik el-Melâ'ike'nin yanı sıra Kasım Emin ile Bekir Yıldız kadın temasını işlemişlerdir. Filistin temasını, Mahmud Derviş ve Nuri Pakdil sırtlanmışlardır. Sol görüşlüler kısmında, Nazım Hikmet ve Selame Musa ortaya çıkmaktadırlar. Karamsarlığı, Cahit Sıtkı ve Nazik el-Melâ'ike işlemiştirler.

Anahtar Kelimeler: Modern Türk Edebiyat1, Modern Arap Edebiyat1, Modern Arap Edebiyatı ve Modern Türk Edebiyatında Benzer Konular ve Yazarları.

\section{SIMILAR SUBJECT IN MODERN ARAB LITERATURE AND MODERN TURKISH LITERATURE AND THEIR WRITERS}

\begin{abstract}
In 1798, Napoleon's invasion of Egypt was a turning point for the Arab World in terms of the relationships with the West. In the Turkish history, the process of adapting to the West has started in 1839, within the Tanzimat period. Similar kinds of works and writers have emerged in both literary worlds. Due to this, "Telemak," was translated by both Yusuf Kâmil Pasa and Rifa't et-Tahtâvi. The first rural
\end{abstract}


novel was given by Nabizade Nazim and Huseyin Heykel. Fuat Köprülü and Sadik er-Rafi are studied on history of the literature. Cemal Kuntay and Taha Huseyin have put forward the three generations of their origins. Ahmet Hamdi Tanpinar and Tevfik el-Hakim have addressed the East-West conflicts. Necip Fazil Kısakürek and Necip el-Keylani have tried to explain the life of the Prophet Muhammad (pbuh) as a novel. Mehmet Akif, Suleyman el-Baruni and Sadik er-Rafi addresses the theme of the homeland. Alongside Nazik el-Mela'ike, Kasim Emin and Bekir Yildiz have taken upon the theme on women. Mahmud Dervis and Nuri Pakdil had taken upon the Palestine as a theme. Nazim Hikmet and Selame Musa appear in the leftist perspective section. Lastly, Cahit Sitki and Nazik el-Mela'ike have taken upon pessimism.

Keywords: Modern Turkish Literature, Modern Arabic Literature, Similar Subjects in Modern Arabic Literature and Modern Turkish Literature and Their Writers.

\section{Giriş: MODERN ARAP EDEBIYYATI VE MODERN TÜRK EDEBIYYATINDA ELE ALINAN BENZER KONULAR VE YAZARLARI}

Modern Arap edebiyatında 1798 yılında, Napolyon'un Mısır'ı işgal etmesi ile başladığı kabul edilmiştir. Bu dönemden sonra Arap dünyasının seçkin edipleri Avrupa'yı ve edebiyatını tanımak için seyahat etmişlerdir. Kendi edebiyatlarında olmasını istedikleri ne varsa modern Arap edebiyatına aktarmışlardır. Tercüme faaliyetleriyle taklitler hız kazanmıştır. Modern Türk edebiyatı ise, 1839'da Tanzimat Fermanı'yla Batı medeniyeti ve edebiyatıyla yakınlaşmışıtır. Tanzimat Dönemi'nden sonra birçok Türk edebiyatçı da Avrupa'ya hayranlıkla eğitim, staj veya kısa bir gezinti için seyahatler düzenlemişlerdir. Batı yaşantısında ve edebiyatında gördükleri yenilikleri modern Türk edebiyatına aktarmak adına bir faaliyet içerisine girmişlerdir. Batı tarzı hikâye, öykü, şiir, roman vs. birçok alanda taklit etmişlerdir. Modern Türk edebiyatında Yusuf Kâmil Paşa, Fransız yazar Fenelon'a ait olan “Telemak” adlı eseri Türkçeye çevirmiştir. Aynı eseri modern Arap edebiyatında Rıfa’t et-Tahtavî, Arapçaya çevirmiştir. Şemsettin Sâmi, Viktor Hugo'nun Sefiller eserini Türkçeye tercüme edip kazandırmıştır. Aynı şekilde Hafız İbrahim de bu esere el-Bu'esa ismini vererek Arapçaya tercüme etmiştir. Modern Türk edebiyatında ilk olarak psikolojik roman türünü Mehmet Rauf, "Eylül" eseriyle vermiştir. Modern Arap edebiyatında da Mahmut el-Akkad, ilk olarak psikolojik eser türünü "Sara" adlı eserle vermiştir. Nabîzade Nazım, modern Türk edebiyatında ilk köy romanını "Karabibik" eseriyle verirken Hüseyin Heykel de "Zeynep" ismiyle modern Arap edebiyatında vermiştir. Mithat Cemal Kuntay "Üç İstanbul” eseriyle modern Türk edebiyatında üçleme örneğini ortaya koyarken Taha Hüseyin ise "Şeceretu'l-Bus (Umutsuzuk Ağacı)" adlı eseriyle modern Arap edebiyatında üç kuşak örneğini ortaya koymuştur. Fuat Köprülü "Türk Edebiyatı Tarihi” adlı eseri kaleme alırken Sadık er-Rafi de "Arap Edebiyatı Tarihi” adlı eseri kaleme alıp edebiyat tarihlerine ışık tutmuşlardır. Ahmet Hamdi Tanpınar "Huzur" isimli romanıyla modern Türk edebiyatında psikolojik ve doğu-batı meselesini ele almıştır. Tevfik el-Hakim de modern Arap edebiyatında psikolojik ve doğu-batı meselesini "Usfur-un Min-eş-Şark" adlı eseriyle ele almıştır. Necip Fazıl Kısakürek “Çöle İnen Nur” adlı eseriyle Necip el-Keylânî de "İlahi Nur" adlı eseriyle, Hz. Muhammed'in (s.a.v.) hayatını roman tarzında anlatmaya çalışmışlardır. Orhan Kemal "Ekmek 
Kavgası" adlı eserinde çiftçinin derdini anlatırken Yusuf İdris de "Erhas Leyâlî (En Uzun Geceler)" adlı eserinde, çiftçinin derdini anlatmıştır.

\section{1-Vatan Teması}

Mehmet Akif Ersoy; eserlerinde vatan, din ve millet gibi temaları çokça işlemiş̧ir. Akif, memleketimizin Vatan Şairi'dir. "İstiklal marşı, Çanakkale Şehitlerine, Ezanlar” gibi ve daha bu minval üzere vermiş olduğu birçok eserleriyle modern Türk edebiyatında vatan ve millet şairi olduğunu ispatlamıştır. Süleyman Başa el-Bârunî, modern Arap edebiyatında vatan şairlerindedir. Libyalı olan el-Bârunî, Libya'nın Akif'i olarak nitelendirilebilir. Libya esarette kaldığı sürece sakalını kesmemek üzere yemin etmiş ve yeminine sadık kalmıştır. El-Bârunî’nin öne çıkan eserleri "el-Esed'ül İslam ve Fi e'imme"dir. Şiirlerinde Osmanlıya olan hasretini, vatan sevgisini ve hürriyet mücadelesini işlemiş̧tir. Her iki şahsiyet de Osmanlının son dönemlerini solumuştur. Akif, Arnavut; Bârunî ise berberi ırkına mensup olmasına rağmen Osmanlı çatısı altında iştiyakla, vatanperverâne mücadele etmişlerdir. İkisi de vatanın bağımsızlığı adına mücadele vermiş ve bu gayreti eserlerinde de göstermişlerdir. Bârunî’nin benzediği gibi Sadık er-Râfî de tıpkı Akif gibi dindar bir şahsiyettir. Aralarındaki benzerlik ise Akif, milletimizin İstiklal Marşı'nı yazmıştır; Sadık ise "Humat'ul-Huma Ya Humat'ul-Huma" diye başlayan Mısır'ın İstiklal Marşı'nı yazmıştır. Öte yandan yaşantı ve edebi anlayış olarak benzer yönleri çok olmasa da Ahmet Şevki ve Akif arasında da bir benzerlik vardır. O benzerlik ise Şevki'nin Abbas Hilmi Paşa'ya eşlik etmek için geldiği zamanlar, olayları bir nevi yakından müşahede ederek Abdülhamid Han'a karşı eleştirilerde bulunmasıdır. Hatta “Osmanlının İnkılabı, Abdülhamid'in İndirilişi”" gibi başlıklarla şiirler yazmıştır. Yoğun propagandaların etkisinde kalarak Akif gibi Abdülhamid'i de eleştirmiştir. Akif ile Şevki arasındaki fark ise Şevki yapmış olduğu eleştiriler için pişman olmuştur; ama Akif olmamıştır.

\section{2-Kadın}

Halide Edip Adıvar, modern Türk edebiyatının ilk kadın yazarlarındadır. Kadın haklarını savunan birçok yazı kaleme almıştır. Halide'nin bu durumuna misal "Vurun Kahpeye" adlı eseridir. Bu eseri, Kurtuluş Savaşı sırasında canını hiçe sayıp feda eden kadınlara ağıt niteliğinde yazmıştır. Teali-i Nisvan Cemiyeti'nin (Kadınları Yükseltme Derneği) kuruluşunda yer almıştır. Nâzik el-Melâ'ike de modern Arap edebiyatında ilk kadın ediplerindedir. Nâzik de kadınların haklarını savunup eserlerinde bu konulara yer vermiştir. Nâzik de Halide'nin kadın cemiyeti kurucusu olması gibi evlilik karşıtı feminist bir derneğin kurucularından olmuştur. Aralarındaki fark ise Nâzik el-Melâ'ike karamsar bir tarza sahip iken Halide Edip Adıvar karamsar değildir.

Bekir Yıldız, modern Türk edebiyatında roman ve öyküleri olan bir yazardır. Yıldız, ağa ve köylü ilişkileri, kan davalarının yanı sıra Güneydoğu'da kadının ezilmişliğini ve kaçakçılık gibi konuları ağırlıkla işlemişti. Kadının ezilmişliğinden bahsettiği "Aile Savaşı, Halkalı Köle ve Kara Çarşaflı Gelin” adlı eserleridir. Kasım Emin de modern Arap edebiyatında başarılı bir romancıdır. Emin, adeta kendini kadın hakları için eser vermeye adamıştır. Arap kadınının sorunlarını çözme fikrine sahiptir. İlk eseri “Tahrir'ul-Mer'e (Kadının Özürlüğü)” adlı eseridir. $\mathrm{Bu}$ eserde kadının açılmasını, eğitimdeki payını elde etmesini ve sosyal hayatta erkekle eşit olmasının gerektiğini ele almıştır. Kasım'ın ikinci eseri “el-Mer'et’ul-Cedide (Yeni Kadın)" kendisine yapılan suçlamalara bir nevi cevap niteliğinde olsa da kadınlar için yazılmış bir başka 
eserdir. Bekir Yıldız ve Kasım Emin, erkek olmalarına rağmen kadınların hakkı için eser vermek cihetiyle birbirlerine benzemektedirler.

Atilla İlhan; sol görüşe yakın, hukuk mezunu bir edebiyatçıdır. Modern Türk edebiyatında intihar, ölüm, ayrılık gibi konular içeren şiirleriyle beraber en değerli konusu aşk ve kadındır. Nizâr Kabbânî de modern Arap edebiyatında hukuk mezunu bir edebiyatçıdır. O da diğer konuların yanı sıra aşk ve kadın şairi olarak bilinmektedir. Atilla ve Nizâr, şiirlerinde cesur ve hoyrattırlar. Her iki şair de kadınlarla ilgili şehevi mısralar kaleme alabilmişlerdir. Atilla'nın "Ben Sana Mecburum, Yasak Sevişmek" adlı şiirleri; Nizâr'ın ise "Esmer Bayan Bana Dedi, Benimsin Sen, Samba, Güzelim" adlı şiirleri aşk ve kadın şairleri olduklarını göstermektedirler.

\section{3-Edebiyat Tarihi}

Fuat Köprülü, Türk edebiyatı tarihçisidir. Türk tarihinin ilk dönemlerine kadar inmiş ve ilk Türk topluluklarının tarih ve edebiyatlarını incelemiştir. Modern Türk edebiyatında önemli bir yere sahip olan "Türk Edebiyat Tarihi" adlı eserini istifadeye sunmuştur. Sadık er-Râfî de modern Arap edebiyatında Fuat Köprülü gibi bir edebiyat tarihçisidir. Sadık da "Arap Edebiyatı Tarihi" adlı eserini modern Arap edebiyatına kazanmıştır. Her iki şahsiyet de kendi edebiyatlarının tarihlerine 1 şı tutmuşlardır. Edebiyat tarihçiliği cihetiyle birbirlerine benzemektedirler.

\section{4-İslamî Konular}

Necip Fazıl Kısakürek, modern Türk edebiyatında; Necip el-Keylânî ise modern Arap edebiyatında İslamî düşünce çerçevesinde eserler vermişlerdir. Modern Türk edebiyatına baktığımızda bu çerçevesinde eserler verip fikirleri uğruna mücadele eden şahsiyetlerden öne çıkanı Necip Fazıl Kısakürek'tir. Aynı şekilde modern Arap edebiyatına baktığımızda Kısakürek tarzı dindar şahsiyetler arasında gelen kişi ise Necip el-Keylânî'dir. Necip Fazıl Kısakürek "Çöle İnen Nur" adlı eseriyle, Necip el-Keylânî de "İlahi Nur" adlı eseriyle Hz. Muhammed'in (s.a.v.) hayatını roman tarzında anlatmaya çalışmışlardır. Her iki şahsiyet de İslam karşıtı olan şahsiyetlere karşı mücadele vermiştir. Hatta İslamî çizgi yönüyle Necip Fazıl Kısakürek, Ali Ahmet Bâkesîr ve Seyyit Kutub ile de benzerlik göstermiştir. Necip Fazıl Kısakürek, İslamî fikir ve düşünceleri için mahkemelerde yargılanıp türlü sıkıntılar çekmiştir. Aynı şekilde el-Keylânî, Bâkesîr, Seyyit Kutup da Mısır'da bu denli sıkıntılarla boğuşmuşlardır.

Cemil Meriç, modern edebiyatımızın kilometre taşlarındandır. Kendisi, düşünür ve fikir adamıdır. Hayatının ilk evrelerinde sosyalist iken okuyup araştırarak ruhi ve fikri bir değişime girmiştir. Tabiri caiz ise İslamî düşünce tarzına bürünmüştür. Çok ince tespitleri ve çözümleri vardır. Sarf ettiği birkaç cümleyle bir kitap dolusu düşünceyi anlatabilmiştir. Buna misal olarak: “Olimpos Dağı'nın çocukları, Hira Dağı'nın evlatlarını asla kabul etmeyecektir.”demiştir. İşte belirttiğimiz gibi üzerine kitap yazılacak bir cümle kurmuştur. Cemil'in en önemli eseri diğerlerini de kapsayan "Bu ülke" adlı eseridir. Abdurrahman Şârkavî de modern Arap edebiyatı için değerli bir şahsiyettir. Şârkavî de hayatının ilk evrelerinde İslamî çizgiye zıt, Marksist iken o da ruhi ve fikri olarak değişim yaşamıştır. İslam'a daha yakın bir hayat tarzını tercih etmiştir. Meriç ve Şârkavî, benzer şekilde ruhi ve fikri değişim yaşamak cihetiyle benzerlik göstermişlerdir. 


\section{5-Filistin}

Nuri Pakdil, modern Türk edebiyatında "Yedi Güzel Adam"dan biridir. Çok küçük yaşlarda okuyup yazmaya başlamıştır. Pakdil, "Anneler ve Kudüs Şairi” olarak bilinmektedir. Deyim yerinde ise edebiyatımızda Kudüs aşığı olarak da bilinir. Pakdil, "Anneler ve Kudüs" adlı eseriyle Kudüs'e olan aşkını göstermiştir. Bu eserinde, şiirlerini okuyup bir yandan anne şefkatini hissederken diğer bir yandan Kudüs gerçekleriyle sınır boylarında savaşan bir savaşçı hissine kapılmak mümkündür. Modern Arap edebiyatında "Filistin Aşı̆̆ı" olan ise Kemal Derviş’tir. Filistinli olan Kemal Derviş; memleketinden uzak, hasretle şiirler yazmıştır. Onun en meşhur eserlerinden biri "Kimlik Kartı" adlı eseridir. Derviş, bu eseriyle Filistin gerçeklerini, özgürlüğünü, sanki İsrail memuru ile konuşup ona sürekli ben Arab'1m deyip sinirlendirircesine yazmıştır. Nuri Pakdil ve Kemal Derviş, iki farklı edebiyatta aynı mesele üzerine hasret ve aşkla titreyen iki güzel şahsiyettir.

\section{6-Sol ve Sosyalist Görüş̧üler}

Nazım Hikmet, modern Türk edebiyatında ilk sol görüşlü yazarlardandır. Komünist olduğu için hapiste bile yatmıştır. Selâme Mûsâ da modern Arap edebiyatında ilk sol görüşlü yazarlarındandır. Her iki şahsiyet de kendilerinden sonra gelen solcu edebiyatçıları etkilemişlerdir. Selâme Mûsâ; Darwin, Spencer, Dostoyevsky, Tolstoy gibi birçok yazar ile tanışıp onlardan etkilenmiştir. Hatta onların etkisiyle "Haula-i Allemuni" adlı eseri kaleme almıştır. Selâme Mûsâ, Mısır Sosyalist Partisi'ni kurmuştur. Nazım Hikmet ise Türkiye Komünist Partisi üyesidir.

\section{7-Kuşak Çatışmasıı}

Mithat Cemal Kuntay, modern Türk edebiyatının önemli şahsiyetlerindendir. Üçleme eseriyle edebiyata hizmet etmiştir. Kuntay'ın en önemli eseri olan “Üç İstanbul” üçleme eseridir. $\mathrm{Bu}$ eserde II. Abdülhamit, II.Meşrutiyet ve Mütareke yıllarının İstanbul'unu anlatmıştır. Gerçekçi kişiler, ayrıntılı tahliller ve bu üç dönemin yaşantısından sunduğu canlı kesitlerle dikkat çeken bu roman, televizyon dizisi olarak da yayınlanmış ve büyük ilgi toplamıştır. Taha Hüseyin ise modern Arap edebiyatının önde gelen isimlerindendir. Bizdeki Aşık Veysel gibi görme yetisini kaybetmiştir. Arap edebiyatında "Şeceretu'l-Bus (Umutsuzuk Ağacı)" adlı eserde de üç kuşak içerisinde bir ailenin hayatını anlatmıştır. Modern Arap edebiyatında "es-Sülasiyye" adlı eseri ile Necip Mahfuz da üçleme eseri ortaya koymuştur. Necip Mahfuz üçleme eserini Taha Hüseyin'in üçleme eserinden etkilenerek kaleme almıştır. Hatta Taha Hüseyin' in eserinde noktaladığı tarihten devralarak devam etmiştir. Cemal Kuntay, Taha Hüseyin ve Necip Mahfuz üçleme eser verme cihetiyle benzemektedirler.

\section{8-Psikolojik Roman}

Modern Türk edebiyatında ilk olarak psikolojik roman türünü Mehmet Rauf "Eylül" eseriyle vermiştir. Abbas Mahmut el-Akkad da modern Arap edebiyatına ilk olarak psikolojik eser türünü "Sara" adlı eserle vermiştir. Rauf arkasından gelen birçok edibi etkilediği gibi Akkad da başka edipleri etkilemiştir. Akkad'dan etkilenenlerin başında Necip Mahfuz gelmiştir. Çünkü o da "Sara" eserinden etkilenip "Serap" adlı eseri kaleme almıştır. 


\section{9-Köy Romanı}

Nabızade Nazım, modern Türk edebiyatında ilk köy romanını "Karabibik" eseriyle veren şahsiyettir. Hüseyin Heykel ise modern Arap edebiyatında ilk köy romanını veren şahsiyettir. Heykel, ilk başlarda Arap toplumunun bir kadın adıyla eser bastırmaya müsait olmadığından dolayı "Menazır-1 Ahlak-1 Rifiye" adıyla bastırmıştır. Bu eser, daha sonraları zeminin de oluşmasının ardından "Zeynep" ismiyle basılmıştır. "Zeynep" eseri, Modern Arap Edebiyatında ilk köy romanı olmuştur.

\section{0-Doğu Batı Çatışması}

Ahmet Hamdi Tanpınar, modern Türk edebiyatında ruh tahlillerini içeren eserler vermiştir. Ahmet Hamdi Tanpınar'ın İhsan, Nuran, Suat ve Mümtaz kahramanlarının isimlerinin verildiği dört bölümden oluşan "Huzur" isimli romanı edebiyatımızın bu alanda yap1 taşlarındandır. Bu eserinde aşkı, psikolojiyi ve Doğu-Batı karşıtlığını ustaca işlemiştir. Tevfik el-Hakim de modern Arap edebiyatında Ahmet Hamdi Tanpınar tarzı eser vermiştir. Tevfik, "Usfur-un Min-eş-Şark (Doğulu Bir Serçe)" adlı eserinde Muhsin karakteriyle adeta kendisini anlatmıştır. Yine bu eserinde ruh tahlilinin yanı sıra Doğu-Batı çatışmasını da işlemiştir. Buradan hareketle her iki şahsiyet de eserlerinin bir kısmında psikoloji ve Doğu-Batı çatışmasına yer vermeleriyle birbirlerine benzemektedirler.

\section{2-Karamsarlık}

Cahit Sitk1 Taranc1, modern Türk edebiyatının karamsar şairidir. Modern Arap edebiyatında ise Nâzik el-Melâ'ike melankolik şair olarak bilinmektedir. Nâzik el-Melâ'ike'nin acısı ve kederi "Ruhum ve Dünyam, Parçalar ve Küller" adlı şiirleriyle kağıtlara sızmıştır. Cahit Sitk1 ise "Ömrümde Sükût, Otuz Beş Yaş, Düşten Güzel" şiirleriyle ile iç dünyasındaki karamsarlı̆̆ı ortaya sermiştir. Cahit ve Nâzik, melankolik tarzlarıla birbirlerine benzemektedirler. Öte yandan Tarancı ile Seyit Kutup da bir noktada kesişmektedirler. Aslında ikili arasında pek fazla bir uyum söz konusu değildir. Seyyit Kutup, mütedeyyin bir şahsiyet ve verdiği eserlerin hemen hemen hepsi dini mücadeleler çerçevesindedir. Tarancı'nın ise ona nazaran pek dindâr olduğu söylenemez. İkiliyi ortada buluşturan Seyit Kutub'un, Cahit Sttk1 Tarancı gibi ölüm şiirinin olmasıdır. İlerleyen yaşın verdiği hüzünle karışık, duygu yüklü bir şiiridir.

Ne dünya eski dünya

Aşırı kederden dönemez durumda

Ne rüzgar eski rüzgar

Sesini içinde gizlemekte

Ne kuşlar eski namelerini söylemede

Bitkin ve perişan bir vaziyette

Ne insanlar eski umutlarında

Ümitsizlikler içinde

Hazana erdi ömrümüz ah!
Yaş otuz beş! Yolun yarısı eder.

Dante gibi ortasındayız ömrün

Delikanlı çağımızdaki cevher,

Yalvarmak, yakarmak nafile bugün

Gözünün yaşına bakmadan gider.

Şakaklarıma kar mı yağdı ne var?

Benim mi Allah'ım bu çizgili yüz?

Ya gözler altındaki mor halkalar?

Neden böyle düşman görünürsünüz, 
Yaklaştı sonumuz eyvah!

Kutup
Y1llar y1lı dost bildiğim aynalar?

Taranc1

\section{3-Politik Eserler}

Modern Türk edebiyatında Orhan Pamuk, Müslüman olarak ikinci Nobel Edebiyat Ödülü’nü alan şahsiyet olmuştur. Pamuk; eserlerinde İstanbulluları, üst tabakayı ve seçkin insanları anlatmıştır. "Cevdet Bey ve Oğulları" adlı eseri üçleme tarzı vermiş olduğu eserdir. Necip Mahfuz ise, modern Arap edebiyatında ilk Müslüman olarak Nobel Edebiyat Ödülü’nü almıştır. Mahfuz da Kahire insanlarını ve seçkin kişileri anlatımıştır. "Beyne'l- Kasreyn, Kasruşevk ve Sükkeriyye" adlı eserleri, üçleme tarzı vermiş olduğu eserdir. Başka bir benzer yönleri ise Necip Mahfuz'a "Sizce ödülü kim hak ederdi?" sorusuna, Taha Hüseyin ve ya Tevfik el-Hakim, diye cevap vermiştir. Aynı soru Orhan Pamuk'a sorulduğunda ise Ahmet Hamdi Tanpınar'ın adını söylemiştir. Pamuk ve Mahfuz; Nobel Edebiyat Ödülü'nü hak etme, üçleme eser verme, konu seçimi ve anlatma tarzında benzerlik göstermişlerdir. Ayrıca ikisine de yöneltilen ödülü sizce kim hak ederdi? sorusuna mütevazılıkla cevap vermişlerdir.

Melih Cevdet Anday, modern Türk edebiyatında eserler vermenin yanı sıra UNESCO'da kültür müşavirliği görevinde bulunmuştur. Cevdet, şiirlerinde toplumsal meselelere yer vermiştir. Buna "Yalan" adlı şiiri örnektir. "Adonis" lakaplı Ali Ahmet Said ise modern Arap edebiyatına katkısıyla beraber Paris’te Arap Birliğinin UNESCO temsilcisi olarak çalışmıştır. Adonis de politik ve Arap toplumunu yakından ilgilendiren eserler kaleme almıştır. Gerek tüm Arap toplumu ve gerekse bir birey olarak kendisi için bir yenilenme, yeniden doğuşu anlatan “el-Ba's ve'r-Remad (Yeniden Doğuş ve Küller)” adlı eseridir.

Orhan Kemal, eserlerinde Çukurova'nın tarım ve fabrika işçilerini, sanayileşme sürecinin getirdiği koşulları, büyük kentlerdeki küçük insanların sorunlarını işlemiştir. Orhan, çiftçinin ve emekçinin mücadelesiyle beraber onların sorunlarını "Ekmek Kavgası" adlı eserinde haykırmıştır. Modern Türk edebiyatında Yaşar Kemal de eserlerinde yoksul tabakayı anlatmıştır, bu konuda onun en önemli eseri "Teneke"dir. Bu eserde bir Anadolu kasabasında çeltikçi ağaların idarelerine karşı çıkan kahramanların ektikleri çeltikler sıtmaya neden olmuştur. İdealist ve genç kaymakam Fikret'in, tüm toyluğuyla beraber ağalarla köylü adına girdiği mücadelesini anlatmıştır. Fakat kaymakam oradan arkasından teneke çalınarak sürgün edilmiştir. Çiftçinin derdini anlatan bir diğer şahsiyet de Fakir Baykurt'tur. Köy yerindeki küçük hesapları, bu hesapların peşinde koşan firsatçıları, onların siyasetteki, bürokrasideki uzantılarını ve o zalimlerin ezmek, yok etmek istediği aydınlık, güzel insanları anlatmıştır. Fakir Baykurt'un en güzel romanlarından biri olan "Yılanların Öcü” memleket meselelerini, köy hayatını, mazlumla zalimin, zenginle fakirin yerini, gücünü, üstünlügünü işlemiştir. Bu ayrımın her yerde olduğunu savunarak köy hayatını, köylünün dilinden anlatarak sunmuştur. Edebiyatımızın en gerçekçi başyapıtlarından biri olmuştur. Yusuf İdris de modern Arap edebiyatında çiftçiyi ve onlarla alakalı fikirlerini eserlerinde anlatımışır. Yusuf İdris, eserlerinde büyük arazi sahiplerinin muazzam kudretiyle, sömürülen çiftçilerin yoksulluğunu karşı karşıya getirmiştir. Çiftçilerin aç ve perişan hayatlarını, hayatlarının sıradanlığını, anlamsızlığını, onların sosyal ve millî meselelere karşı duyarsızlığını dile getirmiştir. Yusuf İdris'in o eseri "Erhas Leyâlî (En Uzun Geceler)"dir. Modern Türk edebiyatında çiftçi ve meselelerini Orhan Kemal, Yaşar Kemal ve Fakir Baykurt işlemiştir. Modern Arap edebiyatında ise bu meseleyi 
Yusuf İdris işlemiştir. Bu şahsiyetler, farklı edebiyatlarda aynı yarayı kaşımak suretiyle benzerlik göstermektedirler. Ayrıca Orhan Kemal ile Yusuf İdris diğerlerinin aksine fikirlerinden dolayı hapis yatmış olmalarıyla da birbirlerine benzemektedirler.

\section{4- Farklı Dillerden Tercümeler}

Yusuf Kâmil Paşa; Arapça, Farsça ve sonraları Fransızca öğrenmiştir. Bir süre Divan-1 Hümayun Kalemi'nde çalışmıştır. Mısır'a gitmiş; Mehmet Ali Paşa'nın güvenini kazanarak önce Mısır Hazine Kâtipliği’ne, sonra da Mehmet Ali Paşa'nın Maiyet Kâtipliği'ne getirilmiştir. Kaymakam rütbesiyle asker olarak mirivalığa dek yükselmiştir. 1845'te Abdülmecit ona Mirmiran rütbesi vermiş. Mehmet Ali Paşa'nın kızı Zeynep Hanım'la evlendirilmiş, Rıfat Tahtavî ise Tanta'da doğmuş ve çocuk yaşta Kâhire'ye gelmişti. Fransa'ya gönderilen heyete başkanlık etmiştir. $\mathrm{O}$ da bu firsatı değerlendirerek Fransızcasını ilerletmişti. Rıfat Tahtavî, Mısır'a dönünce Kavalalı Mehmet Ali Paşa'nın yaptırdığı sanat okullarında tercümanlık görevini ifa eder. Daha sonrada Dil Okulu Müdürlüğü'ne getirilir. Kâmil Paşa ve Tahtavî, önemli görevler icra etmiştir. Her ikisi de Mısır'ın o dönemine şahittirler. Kamil Paşa'nın dilimize çevirdiği "Fenélon'un Telemaque'ı (Telemak)" Türkçe yayınlanan ilk çeviri romandır. Aynı şekilde Rıfat Tahtavî de aynı eseri Arapçaya çevirmiştir. Bazı kaynaklarda belki Yusuf Paşa bu kitabı çevirirken Tahtavî'nin çevirisinden istifade etmiştir. İki şahsiyet de kendi edebiyatlarında batılılaşmanın öncüsü sayılmıştır.

Şemsettin Sâmi, dilci olarak tanınsa da edebiyatın birçok türüyle de ilgilenmiştir. Türk edebiyatı tarihinde ilk yerli roman olma özelliğine sahip olan "Taaşşuk-1 Talat ve Fıtnat" adlı eseri kaleme almıştır. Taaşşuk-1 Talat ve Fitnat eseri, roman olarak vermiş olduğu tek eserdir. Asıl işi lügatçilik ve ansiklopediciliktir. Viktor Hugo'nun "Sefiller" eserini Türkçeye tercüme edip kazandırmıştır. Modern Arap edebiyatında Hafız İbrahim ise roman anlayışı olarak Şemsettin Sâmi'ye benzetilmektedir. Hafız da "Leyâl-î Satıh" adlı eseriyle roman alanında tek eser vermiştir. Hafiz, Sâmi gibi "Sefiller" eserine el-Bu' esa ismini vererek Arapçaya tercüme etmiştir. Modern Arap edebiyatında Hafiz gibi Sefiller eserini Necip Gargur da Arapçaya tercüme etmiştir. Ancak Necip Gargur, "Sefiller" eserini "et-Tuesa" olarak isimlendirmiştir. Necip Gargur ve Şemsettin Sâmi’nin ortak yönü ise "Sefiller" eserinin çevirisidir.

\section{SONUÇ}

Modern Türk Edebiyatı, 1839'da Tanzimat Fermanı'yla Batı medeniyeti ve edebiyatıyla yakınlaşmışır. Batı'ya ayak uydurarak onu taklit etmeye başlamışlardır. Batı tarzı hikâye, öykü, şiir, roman vs. birçok alanda Batı'yı taklit etmişlerdir. Modern Arap Edebiyatında ise 1798 yılında, Napolyon'un Mısır'ı işgal etmesi ile adaptasyon süreci başlamıştır. Arap dünyası da Batı'ya ayak uydurmaya başlamıştır. Modern Arap Edebiyatı'na birçok türü kazandırmışlardır. Modern Türk ve Arap edebiyatında birbirine benzer tarzda hadiseler cereyan etmiştir. Dolayısıyla her iki edebiyatta benzer türler ve eserler ortaya çıkmıştır.

Vatan temasında Mehmet Akif, Süleyman Başa el-Bârunî, Sadık er-Râfî karşımıza çıkmaktadırlar. Süleyman Başa el-Bârunî Libya'nın M.Akif'i olarak nitelendirilmektedir. Sadık er-Râfî de Mısır'ın İstiklal marşını nakşetmiştir.

Kadın temasında ise iki farklı güruh bulunmaktadır. Halide Edip Adıvar, Nâzik elMelâ’ike, Bekir Yıldız ve Kasım Emin gibi kadınların haksızlığa uğradıklarını ve haklarını 
almaları için mücadele edenlerdir. Diğeri ise Atilla İlhan ile Nizar Kabbânî gibi kadın ve aşk temasını işleyenlerden oluşmaktadır.

Mehmet Rauf ile Mahmut el-Akkad ilk psikolojik eserleri verenler olarak meydanda belirmişlerdir. Modern Türk edebiyatında ilk olarak psikolojik roman türünü Mehmet Rauf "Eylül” eseriyle Abbas Mahmut el-Akkad da Arap edebiyatına ilk olarak psikolojik eser türünü "Sara" adlı eserle vermiştir.

İlk köy romanı konusunda Nabızade Nazım ile Hüseyin Heykel başı çekmişlerdir. Nabızade Nazım, modern Türk edebiyatında ilk köy romanını "Karabibik" eseriyle vermiştir. Hüseyin Heykel ise ilk başlarda Arap toplumunun bir kadın adıyla eser bastırmaya müsait olmadığından ötürü "Menazır-1 Ahlak-1 Rifiye" adıyla bastırmıştır. Bu eser, daha sonraları zeminin de oluşmasının ardından "Zeynep" ismiyle basılmıştır. "Zeynep" eseri, modern Arap edebiyatında ilk köy romanı olmuştur.

Üç kuşağın hayatını gözler önüne serip kuşak çatışmasını, Mithat Cemal ile Taha Hüseyin ele almışlardır. Kuntay'ın en önemli eseri olan "Üç İstanbul” üçleme eseridir. Bu eserde II. Abdülhamit, II.Meşrutiyet ve Mütareke yıllarının İstanbul'unu anlatmıştır. Taha Hüseyin ise Arap edebiyatında "Şeceretu'l-Bus (Umutsuzuk Ağacı)" adlı eserde de üç kuşak içerisinde bir ailenin hayatını anlatmıştır.

Başka kısımlarda eserler vermelerinin yanı sıra edebiyat tarihlerini ele alarak benzeyenler de Fuat Köprülü ile Sadık er-Râfî olmuştur. Fuat Köprülü, Türk tarihinin ilk dönemlerine kadar inmiş ve ilk Türk topluluklarının tarih ve edebiyatlarını incelemiştir. "Türk Edebiyat Tarihi" adlı eserini vermiştir. Sadık da "Arap Edebiyatı Tarihi” adlı eserini modern Arap edebiyatına kazanmıştır.

Hamdi Tanpınar ile Tevfik el-Hakim eserlerinde psikolojiyle beraber Doğu Batı çatışmasını ele almışlardır. Ahmet Hamdi Tanpınar'ın dört bölümden oluşan "Huzur" isimli romanı edebiyatımızda bu tarz eserlerin başında gelmektedir. Bu eserinde aşkı, psikolojiyi ve Doğu-Batı karşıtlığını işlemiş̧tir. Tevfik el-Hakim de "Usfur-un Min-eş-Şark (Doğulu Bir Serçe)" adlı eserinde Muhsin karakteriyle adeta kendisini anlatmıştır. Yine bu eserinde ruh tahlilinin yanı sıra Doğu-Batı çatışmasını da işlemiştir.

Necip Fazıl Kısakürek ile Necip el-Keylânî, İslamî fikir dünyaları ile ön plana çıkmaktadırlar. Bu minval üzere yaşayıp eser vermişlerdir. Necip Fazıl Kısakürek "Çöle İnen Nur" adlı eseriyle, Necip el-Keylânî de "İlahi Nur" adlı eseriyle Hz. Muhammed'in (s.a.v.) hayatını roman tarzında konu edinmişlerdir.

Orhan Kemal ile de Yusuf İdris çiftçinin derdini haykırırken benzerlik göstermişlerdir. Orhan, eserlerinde Çukurova'nın tarım ve fabrika işçilerini, sanayileşme sürecinin getirdiği koşulları, büyük kentlerdeki küçük insanların meselelerini ele almıştır. Çiftçinin ve emekçinin mücadelesiyle beraber onların sorunlarını ''Ekmek Kavgası” adlı eserinde haykırmıştır. Yusuf İdris de eserlerinde büyük arazi sahiplerinin muazzam kudretiyle, sömürülen çiftçilerin yoksulluğunu karşı karşıya getirmiştir. Çiftçilerin aç ve perişan hayatlarını, hayatlarının sıradanlığını, anlamsızlığını, onların sosyal ve millî meselelere karşı duyarsızlığını dile getirmiştir. Yusuf İdris'in önemli eseri ise "Erhas Leyâlî" eseridir. 
Cahit Sitkı Tarancı ve Nâzik el-Melâ'ike karamsar şairlerdir. Nâzik el-Melâ'ike'nin acısı ve kederi "Ruhum ve Dünyam, Parçalar ve Küller" adlı şiirleriyle ortaya çıkmıştır. Cahit Sttkı ise "Ömrümde Sükût, Otuz Beş Yaş, Düşten Güzel” şiirleriyle ile iç dünyasındaki karamsarlığ ortaya sermiştir.

Sol ve sosyalist görüş sahipleri kısmında, Nazım Hikmet ve Selâme Mûsâ belirgin bir şekilde ortaya çıkmaktadırlar. Selâme Mûsâ, Mısır Sosyalist Partisi'ni kurmuştur. Nazım Hikmet ise Türkiye Komünist Partisi üyesi olmuştur.

Nuri Pakdil ve Mahmut Derviş, Kudüs aşığıdırlar. Pakdil, "Anneler ve Kudüs” adlı eseriyle Kudüs'e olan aşkını ortaya koymuştur. Kemal Derviş ise "Kimlik Kartı" eseriyle Filistin gerçeklerini yazmıştır.

Yusuf Kâmil Paşa ile Rifa't et-Tahtavî, “Fenélon'un Telemaque'1 (Telemak)” adlı eserini tercüme etmişlerdir. Kimilerine göre Kamil Paşa kendi yaptığı çeviri de Tahtavî’nin Arapça tercümesinden istifade etmiş olabilir kanısındalardır. Şemsettin Sâmi, Hafız İbrahim ve Necip Gargur Viktor Hugo'nun “Sefiller” eseri tercüme etmişlerdir. Hafız İbrahim “el-Bu'esa” olarak isimlendirmiştir. Necip Gargur ise "et-Tuesa” olarak isimlendirmiştir.

\section{KAYNAKLAR}

Er, Rahmi, Modern Misır Roman1-I (1914-1944), Hece Yayıncılık, 2015-Ankara, 1. bs.

Geçgel, Hulusi, Cumhuriyet Dönemi Türk Edebiyatı, Anı Yayıncılık, 2011-Ankara, 3. bs. S. 43 51, 54-71, 84-95, 138-141, 236-241, 271-278, 311-315, 326-332, 345-352, 374-383.

Gür, Âlim ve ENGİN Ertan (Eds.) Cumhuriyet Dönemi Türk Edebiyatı, Akçağ Yayınları, 2015Ankara, 1.bs. S. 321-342, 603-609.

Kayabaşı, Ali Malik, Türk Edebiyatı Çekirdek Bilgileri, Anka Eğitim Yayınları, 2011

Korkmaz, Ramazan (Ed.) Yeni Türk Edebiyatı 1839-2000, Grafiker Yayınları, 2016-Ankara, 11. bs. S. 158-162, 223-227, 252-256.

Landau, J.M. (1994) Modern Arap Edebiyatı Tarihi (20. Yüzy1l), (Dr. B. Aytaç çev.). Ankara: Gündoğan Yayınları.

Tekin, Arslan, Edebiyatımızda İsimler ve Terimler, Bilgeoğuz Yayınları, 2010-İstanbul, 4.bs. S. 20, 79, 166-167, 377-379, 545-546, 642-644, 673-674, 682, 729-730, 740-741, 808, 824-825, 865-866, 905-906, 1042-1045, 1066-1068, 1076-1077, 1195-1196, 1210$1211,1221$.

Ürün, Ahmet Kazım, Modern Arap Edebiyatı, Çizgi Kitabevi Yayınları, 2015-Konya, S. 13-28, 33-38, 51-54, 63-65, 67-69, 75-85, 92-94, 96, 112-116, 119-122, 124-129, 139-143,

Ürün, Ahmet Kazım, “'Modern Arap Edebiyatında Öne Çıkan Bazı Temalar." Some Prominent Themes In Modern Arab Literature. 2016 (35) 